\title{
REPRESENTAÇÃO E VIDA COTIDIANA NO CENTRO
}

\author{
Leandro Medrano
}

Uma das inaugurações mais festejadas deste ano de 2018 foi o Sesc 24 de Maio, projeto do arquiteto Paulo Mendes da Rocha e do escritório MMBB. Sua arquitetura singular e a especificidade urbana do local permitem que sua análise ganhe uma dimensão ampliada não se trata apenas de um edifício, mas das relações de suas formas, espaços e programa com o cotidiano urbano do centro histórico da maior cidade da América Latina.

Algumas especificidades do Sesc 24 de Maio são especialmente interessantes à arquitetura, ao urbanismo e ao design. Por estar situado na região central da cidade de São Paulo, retoma as narrativas relacionadas à região, intensificadas nas últimas décadas. Tida como degradada desde a década de setenta, não foram poucas as pesquisas e projetos relacionados à área, pois suas especificidades históricas, sociais, tipológicas e espaciais alimentam temas como o das políticas urbanas, ativismo social, gentrificação, habitação de interesse social, mobilidade, governança, violência, imigração, espaços públicos, espaços comuns (commons), arte, cultura, entre outros. Trata-se de um rico e complexo objeto de estudo, uma fonte de dados e informações de grande relevância aos estudos acadêmicos nos campos dedicados à forma e ao espaço. Por isso, o novo Sesc paulistano, situado em uma das áreas mais críticas do centro, desperta a atenção dos que estudam a cidade - seu impacto deve ser significativo, pois potencia valores locais e sinaliza novos e promissores rumos à região.

Mas qual o papel da arquitetura, do urbanismo e do design nesse processo? Há tempos que a cidade tornou-se um tema central a essas disciplinas, pois intensifica-se o entendimento de que vivemos em uma sociedade urbana, na qual as cidades são objeto central dos seus impulsos de transformação. Aliam-se à ideia de um território global, rural e urbano, conectado física e virtualmente por meio de redes de comércio, imigração, cultura e turismo. Desfeitas as condições históricas que permitiram a formação de um ideal de Cidade (talvez uma ideologia ocidental), a forma dessa Cidade tornase indefinida nesse início de século. Os códigos são outros, bem

DOI: HTTP://DX.DOI.ORG/IO.II606/ISSN.23I7-2762.v2si45p9-IO

Pós, Rev. Programa Pós-Grad. Arquit. Urban. FAUUSP. São Paulo, v. 25, n. 47 p. 9-10, set-dez 2018 
como a natureza dos seus agentes de transformação e suas conformações espaciais. Definir sua forma e espaço é uma tarefa interdisciplinar, uma heterologia, que exige a construção sistemática de saberes por meio do exercício da inovação e da avaliação continuada.

Nesse sentido, justificam-se os votos de apoio e esperança dado ao Sesc 24 de Maio, pois dentro de circunstâncias restritas e de processos adversos, a junção entre arquitetura e urbanidade parece promissora. Sobretudo por estar aliada à competente administração do Sesc, que tem assegurado em suas unidades programas de singular competência nas áreas da cultura, arte, educação e esportes. Antes dos manifestos dos anos 1990 que buscaram aproximar a arquitetura do programa, o Sesc parecia já ter intuído que programa e arquitetura têm relações que ultrapassam o sentido imediato das necessidades práticas. E por isso tal união tem sido objeto de diversas pesquisas acadêmicas publicadas e em andamento. No caso específico do Sesc 24 de Maio, essa relação é ainda mais intensa, pois pretende fazer Cidade em ambiente urbano cuja história revela suas potências e fragilidades.

As universidades, as pesquisas e seus meios de divulgação devem estar atentos para que certas conquistas não se desfaçam pelo arbítrio primário das forças regressivas. É um papel da crítica e da estética, indispensáveis às disciplinas que pensam e determinam o espaço e suas relações.

Boa leitura!

\section{Leandro Medrano}

Editor Chefe 